\title{
The role of genotype in Familial Mediterranean Fever
}

\author{
Semanur Özdel ${ }^{1}$, Zeynep Birsin Özçakar ${ }^{1 *}$, Seda Sahin², Mesiha Ekim, Atilla Elhan ${ }^{3}$ Fatos Yalcinkaya \\ From 21st European Pediatric Rheumatology (PReS) Congress \\ Belgrade, Serbia. 17-21 September 2014
}

\section{Introduction}

Familial Mediterranean Fever (FMF) is an autosomal recessive disease, characterised by recurrent, self limited attacks of fever with serositis. The gene responsible for FMF, designated as $M E F V$, encodes pyrin.

\section{Objectives}

The aim of this study was to compare the demographic and clinical features of FMF patients with heterozygous $M E F V$ mutations to those with homozygous or compound heterozygous mutations.

\section{Methods}

Files of patients who had been seen in our department (during routine follow-up visits) between January 2013 and January 2014 were retrospectively evaluated. Six predominant mutations (p.M694V, p.M680I, p.M694I, p.V726A, p.K695R, p.E148Q) in the MEFV gene were studied in our center. Patients were divided into two groups: group I included patients with heterozygous mutations and group II included patients with homozygous or compound heterozygous mutations.

\section{Results}

The study group comprised 263 FMF patients (145 females, 118 males) with a mean age of $9.7 \pm 5.2$ years. There were 83 patients in group I and 180 patients in Group II. Although age at disease onset and clinical findings did not differ between the two groups, age at onset of colchicine therapy was lower in group II $(\mathrm{p}<0,05)$ patients. Family history of FMF was more frequently detected in group II $(\mathrm{p}=0,016)$. Acute phase reactant levels during the attacks before colchicine therapy and the attack-free period after colchicine therapy were higher in group II

${ }^{1}$ Pediatric Rheumatology, Ankara University, Ankara, Turkey

Full list of author information is available at the end of the article $(\mathrm{p}<0,05)$. Median PRAS severity score and final colchicine dosages were also higher in group II $(\mathrm{p}<0,05)$ patients.

\section{Conclusion}

As an expected finding FMF patients with homozygous and compound heterozygous mutations have more severe disease during childhood period.

\section{Disclosure of interest}

None declared.

\section{Authors' details}

${ }^{1}$ Pediatric Rheumatology, Ankara University, Ankara, Turkey. ${ }^{2}$ Pediatrics, Ankara University, Ankara, Turkey. ${ }^{3}$ Biostatistics, Ankara University, Ankara, Turkey.

Published: 17 September 2014

doi:10.1186/1546-0096-12-S1-P261

Cite this article as: Özdel et al:: The role of genotype in Familial Mediterranean Fever. Pediatric Rheumatology 2014 12(Suppl 1):P261.
Submit your next manuscript to BioMed Central and take full advantage of:

- Convenient online submission

- Thorough peer review

- No space constraints or color figure charges

- Immediate publication on acceptance

- Inclusion in PubMed, CAS, Scopus and Google Scholar

- Research which is freely available for redistribution
() Biomed Central
C Biomed Central

(c) 2014 Özdel et al; licensee BioMed Central Ltd. This is an Open Access article distributed under the terms of the Creative Commons Attribution License (http://creativecommons.org/licenses/by/4.0), which permits unrestricted use, distribution, and reproduction in any medium, provided the original work is properly cited. The Creative Commons Public Domain Dedication waiver (http://creativecommons.org/publicdomain/zero/1.0/) applies to the data made available in this article, unless otherwise stated. 